\title{
Influence of cactus mucilage and marine brown algae extract on the compressive strength and durability of concrete
}

\author{
E.F. Hernández ${ }^{a}$, P.F. de J. Cano-Barrita ${ }^{\mathrm{a}} \bowtie$, A.A. Torres-Acosta ${ }^{\mathrm{b}}$ \\ a. Instituto Politécnico Nacional/CIIDIR Unidad Oaxaca, (Santa Cruz Xoxocotlán, Oaxaca, México) \\ b. Universidad Marista de Querétaro, (Querétaro, México) \\ $\triangle$ pcano@ipn.mx
}

\author{
Received 28 october 2014 \\ Accepted 3 June 2015 \\ Available on line 15 january 2016
}

\begin{abstract}
This paper presents the mechanical performance and durability of concrete with water/cement (w/c) ratios of 0.30 and 0.60 containing cactus mucilage and brown marine seaweed extract solutions (at $0.5^{\circ}$ Brix concentrations). Cylindrical specimens $(100 \mathrm{~mm} \times 200 \mathrm{~mm})$ were cast and moist-cured for 0 and 28 days. Compressive strength, rapid chloride permeability, and chloride diffusion tests were conducted to evaluate all of the concrete mixes at the ages of 60 and 120 days. In addition, accelerated carbonation tests were carried out on specimens at the age of 180 days by exposure to $23{ }^{\circ} \mathrm{C}, 60 \% \mathrm{RH}$ and at $4.4 \% \mathrm{CO}_{2}$ for 120 days. The compressive strength results showed that only one concrete mix with admixtures increased in strength compared to the control. Regarding the rapid chloride permeability, chloride diffusion and carbonation, the results indicated that the durability of concretes containing organic additions was enhanced compared to the control.
\end{abstract}

KEYWORDS: Concrete; Organic admixtures; Compressive strength; Chloride; Durability

Citation/Citar como: Hernández, E.F.; de Cano-Barrita, P.F. de J.; Torres-Acosta, A.A. (2016) Influence of cactus mucilage and marine brown algae extract on the compressive strength and durability of concrete. Mater. Construcc. 66 [321], e074. http://dx.doi.org/10.3989/mc.2016.07514.

RESUMEN: Influencia del mucílago de cactus y extracto de algas pardas marinas en la resistencia a compresión y durabilidad del hormigón. Este trabajo presenta el comportamiento mecánico y de durabilidad de concretos con relaciones agua/cemento de 0.30 y 0.60 , conteniendo soluciones de mucílago de nopal y extracto de algas marinas cafés $\left(0.5^{\circ}\right.$ Brix de concentración). Especímenes cilíndricos $(100 \mathrm{~mm} \times 200 \mathrm{~mm})$ fueron elaborados y curados en húmedo por 0 y 28 días. Se evaluó la resistencia a la compresión, permeabilidad rápida y difusión de cloruros a los 60 y 120 días de edad. Adicionalmente, se realizaron pruebas de carbonatación acelerada en especímenes con 180 días de edad, expuestos a $23{ }^{\circ} \mathrm{C}, 60 \% \mathrm{HR}$ y $4.4 \%$ de $\mathrm{CO}_{2}$ por 120 días. Los resultados de resistencia a la compresión muestran que únicamente una mezcla de concreto con adición orgánica incrementó su resistencia con respecto al control. Con respecto a la permeabilidad rápida a cloruros, difusión de cloruros y carbonatación, los resultados indican que la durabilidad de los concretos que contenían adiciones orgánicas fue mejorada con respecto al control.

PALABRAS CLAVE: Hormigón; Aditivos orgánicos; Resistencia a la compresión; Cloruros; Durabilidad

Copyright: (C) 2016 CSIC. This is an open-access article distributed under the terms of the Creative Commons Attribution-Non Commercial (by-nc) Spain 3.0 License. 


\section{INTRODUCTION}

Premature deterioration of reinforced concrete structures represents a serious durability problem. Understanding the factors that affect the durability of concrete proves useful in proposing solutions to improve the performance. One of the primary causes of deterioration is the corrosion of the reinforcing steel embedded in concrete (1). Steel corrosion in reinforced concrete structures is mainly due to the ingress of chloride ions and carbonation of the concrete cover. The high alkalinity of concrete $(\mathrm{pH} \approx 13)$ forms an oxide protective layer around the steel rebars that is lost when carbonation decreases the $\mathrm{pH}$ below 9 or with the entry of chloride ions or under both scenarios $(2,3)$. As such, the durability of a reinforced concrete structure is dependent on the concrete's resistance to the penetration of aggressive agents $(4,5)$.

High performance concrete (HPC) was developed in response to known durability problems in reinforced concrete structures exposed to a harsh environment. HPC is characterized by its low water/ cementitious materials ratio and by the use of chemical and mineral admixtures to reduce permeability and increase durability (6). Various protective methods such as corrosion inhibitors, cathodic protection, epoxy and metallic coatings have also been applied to decrease steel corrosion (7). HPC may have a moderate cost increase with respect to ordinary concrete owing to the use of chemical and mineral admixtures. Similarly, while corrosion protection methods increase the time for corrosion initiation, some increase the ultimate cost of concrete and are not environmentally friendly $(8,9)$.

The addition of organic materials has been the focus of several studies as a sustainable alternative to improve the mechanical properties and durability of cement-based materials. One such admixture is cactus mucilage, which has previously been used in lime mortars, with the aim of providing a preliminary scientific explanation related to the ancestral use of cactus mucilage as a lime adhesive and waterproofing admixture (10). The lime pastes made with higher mucilage/lime ratios had an increased fracture resistance. Chandra et al. (11) studied the interaction between cactus mucilage and Portland cement in mortar with a w/c ratio of 0.50 . They observed improved workability in fresh mortar containing cactus extract. In hardened mortar, the compressive strength at 1,7 , and 28 days was always lower than that of the control. However, at 90 days of age, the strength was $12 \%$ higher than the control. In addition, the drying rate was slowed due to the water retention capacity of the mucilage, and the water absorption was also reduced. On a micro-structural level, they observed the formation of small crystallites instead of the large crystals of calcium hydroxide commonly found in hydrated cement paste. Hernandez-Zaragoza et al.
(12) studied Portland cement mortar with a w/c ratio of 0.60 containing lyophilized cactus gum. Their results indicated a $65 \%$ compressive strength increase with respect to the control mortar at only three days of age, which is contrary to other studies in which the addition of cactus mucilage extended the setting times and also negatively affected the compressive strength gain at early ages as well as at 28 days $(11,13)$. Moreover, their results fail to provide a clear trend for either increasing or decreasing compressive strength with increasing lyophilized cactus gum concentration. Ramírez et al. (13) used a cactus mucilage solution to investigate its effects on the properties of concrete in a fresh state, on durability in a hardened state, and on the micro-structural changes in cement paste. The viscosity and setting times of the cement paste increased with the use of a cactus mucilage solution. In the microstructure, the formation of calcium hydroxide crystals was not observed. X-ray diffraction analysis also showed the retardant effect on the hydration process. Regarding durability, the capillary water uptake and the chloride diffusion coefficients decreased. León-Martínez et al. (14) successfully used cactus mucilage and marine brown algae extract as a viscosity-enhancing admixture for self-consolidating concrete. Torres-Acosta (15) evaluated the effect of two dehydrated cacti (Opuntia ficus indica and Aloe Vera) as corrosion inhibitors in alkaline media. Their results showed good corrosion inhibiting effect on reinforcing steel when chloride ions were present, especially when dehydrated nopal was used at $1 \%$ and $2 \%$ by mass.

Alginate, a salt deriving from the alginic acid obtained from marine brown algae, is another type of organic admixture that has been used to improve the performance of construction materials. Alginate is a polysaccharide composed of a binary nonbranched co-polymer from mannuronic $(\mathrm{M})$ and $\alpha$-L guluronic $(\mathrm{G})$ acids $(16,17)$. These hydrocolloids have the capacity to gel through interaction with carboxylic groups and divalent ions $(18,19)$. A seaweed extract containing sodium alginate has been used, along with sheep wool, as a soil stabilizer in the elaboration of a sustainable composite for the construction industry (20). The combination of alginate $(19.5 \% \mathrm{w} / \mathrm{w})$ and wool $(0.25 \% \mathrm{w} / \mathrm{w})$ increased both the compressive and flexural strength, obtaining values comparable to those obtained with Portland cement $(10 \% \mathrm{w} / \mathrm{w})$. This combination has also been used to improve cement hydration due to its water retention capacity, which allows for a higher degree of hydration (21).

Mineral admixtures are well known alternatives for increasing the mechanical strength and durability of reinforced concrete structures. However, their use is restricted to places where they are economically available. Based on the literature review, cactus mucilage and marine brown algae extract have demonstrated their suitability as viscosity 
enhancing admixtures for self-consolidating concrete (SCC), and understanding their effect on the mechanical performance and durability of ordinary and high performance concrete is important for applications where SCC is not required. The objective of this work is to assess the mechanical performance and durability of concrete containing cactus mucilage and marine brown algae extract solutions.

\section{MATERIALS AND METHODS}

\subsection{Materials}

\subsubsection{Portland cement}

Sulfate resistant ordinary Portland cement (CPO 30RS according to the Mexican cement denomination) was used. This type of cement was selected because it was the only one in the market with a low content of mineral additions. Its chemical composition is given in Table 1 .

\subsubsection{Fine and coarse aggregates}

River sand and gravel were used as fine and coarse aggregates, respectively. Their physical properties are given in Table 2. The characterization of

TABle 1. Chemical composition of CPO-30RS cement

\begin{tabular}{lr}
\hline Compound & \multicolumn{1}{c}{$\%$} \\
\hline $\mathrm{SiO}_{2}$ & 18.77 \\
$\mathrm{Al}_{2} \mathrm{O}_{3}$ & 3.69 \\
$\mathrm{Fe}_{2} \mathrm{O}_{3}$ & 3.97 \\
$\mathrm{CaO}$ & 58.77 \\
$\mathrm{MgO}$ & 1.58 \\
$\mathrm{~K}_{2} \mathrm{O}+\mathrm{Na}_{2} \mathrm{O}$ & 0.49 \\
$\mathrm{Fe}$ & 2.78 \\
$\mathrm{MnO}$ & 0.10 \\
$\mathrm{P}_{2} \mathrm{O}_{5}$ & 0.10 \\
$\mathrm{TiO}_{2}$ & 0.17 \\
$\mathrm{SO}_{3}$ & 2.54 \\
$\mathrm{PXC}$ & 5.39 \\
\hline
\end{tabular}

TABLE 2. Physical properties of fine and coarse aggregates

\begin{tabular}{lcc}
\hline Property & Fine Aggregate & Coarse Aggregate \\
\hline Maximum size $(\mathrm{mm})$ & - & 9.50 \\
Bulk density $\left(\mathrm{kg} / \mathrm{m}^{3}\right)$ & 1621 & 1448 \\
Specific gravity & 2.59 & 2.50 \\
Water absorption $(\%)$ & 2.08 & 2.98 \\
Fineness modulus & 2.67 & \\
\hline
\end{tabular}

the aggregates was carried out in accordance with the standards ASTM C33 (22), ASTM C70 (23), ASTM C127 (24), ASTM C128 (25), ASTM C566 (26), and ASTM C29 (27).

\subsubsection{Organic admixtures}

2.1.3.1. Cactus mucilage. A cactus mucilage solution with a $0.50{ }^{\circ}$ Brix $(0.42 \% \mathrm{w} / \mathrm{v})$ concentration was used. This solution was extracted from the cladodes of Opuntia ficus índica cactus. The mucilage is a complex carbohydrate with excellent water absorption capacity, a high molecular weight and poly-electrolyte behavior (28). The mucilage is envisaged as a potential source of hydrocolloids that could be used as a thickening agent in the pharmaceutical and food industry (29-31). This polymer is a polysaccharide with arabinose, galactose, galacturonic acid, rhamnose and xylose residues $(32,33)$. The mucilage extraction consisted of mixing strips of cactus with distilled water in a 1:1.5 (w/w) proportion at a controlled temperature of no more than $60{ }^{\circ} \mathrm{C}$ for $3 \mathrm{~h}$. The obtained cactus mucilage solution was the result of progressive filtering through sieves No. $16(1.18 \mathrm{~mm})$, No. $100(150 \mu \mathrm{m})$ and No. 200 $(74 \mu \mathrm{m})$.

2.1.3.2. Marine brown algae extract. Commercial concentrated algae dispersion from marine brown algae Macrocystis pyrifera was used. The dispersion consists of a liquid phase containing some free amino acids, free ions, sugars, pigments and colloidal polysaccharides such as alginates, laminaran, mannitol, fucoidan and proteins as well as another phase composed of ground leaves and stems. The main polysaccharide in the seaweed extract is alginate (16), which represents between $25-33 \%$ of the dry weight of the algae. The extract was obtained by mixing the concentrated paste with distilled water in a $1: 1(\mathrm{v} / \mathrm{v})$ proportion. A thermal bath at a temperature not exceeding $50{ }^{\circ} \mathrm{C}$ was used to facilitate the filtration through a sieve No. $100(150 \mu \mathrm{m})$. The concentration of the final solution was $0.50{ }^{\circ} \mathrm{Brix}$ $(0.42 \% \mathrm{w} / \mathrm{v})$.

\subsection{Rheological measurements in aqueous solutions containing organic admixtures}

Rheological measurements of cactus mucilage and seaweed extract solutions at different concentrations were performed with a controlled-stress rheometer (Anton Paar, model Physica MCR301). A doublegap concentric cylinder (model DG26.7-SN21085) and a Peltier system (C-PTD200) were used. The solutions were characterized based on their steadyshear viscosity $\eta$ using a unidirectional steady-shear flow with shear rates ranging from 0.01 to $600 \mathrm{~s}^{-1}$. The data analysis was performed using the software Rheoplus/32 version 3.0. To compare the effect of 
concentration on the rheological properties, the data obtained from the admixtures was fit to a Herschel-Bulkley model (34) and the consistency index obtained was plotted versus concentration. In all of the fittings, the coefficient of determination was greater than 0.98. Additional measurements of cactus mucilage at $1.38 \%$ with calcium hydroxide (0.0156 M, 0.0312 M, 0.0625 M, 0.125 M, 0.25 M, $0.50 \mathrm{M}, 0.75 \mathrm{M}$ and $1.00 \mathrm{M}$ ) were performed. For the seaweed extract solution it was not possible to make rheological measurements with different concentrations of calcium hydroxide, because of the gelling behavior of this solution even at low concentrations of calcium hydroxide.

\subsection{Degree of hydration and pore size distribution}

Cement pastes with water/cement ratios (w/c) of 0.30 and 0.60 were prepared according to the standard ASTM 305 (35). Cactus mucilage and seaweed extract were used in solutions at $0.5 \%$, $1.0 \%$ and $1.82 \%(\mathrm{w} / \mathrm{v})$ concentration to replace the mixing water. Cylindrical specimens with $40 \mathrm{~mm}$ diameter and $80 \mathrm{~mm}$ height were cast from each paste and cured under moist (W) and sealed (S) conditions. The degree of hydration by the ignition method (36) was obtained at 28 days, 120 days and 1 year. The NMR measurements to determine the pore size distribution were performed on 1-yearold samples under sealed curing, using an Oxford Instruments Model Maran DRX-HF 12/50 spectrometer (Oxford Instruments, Abingdon, UK) at $12.90 \mathrm{MHz}$. The CPMG (Carr-Purcell-MeiboomGill) (37) technique was used to obtain the transverse magnetization decay, which was in all cases best fit to a bi-exponential decay function to determine the NMR signal amplitude and the $T_{2}$ decay components.

\subsection{Concrete mix proportions}

Concrete mixes with w/c ratios of 0.30 and 0.60 were designed according to the method proposed by Aitcin and Mehta (38) and the Absolute Volumes Method of the ACI (39), respectively. The organic admixtures, cactus mucilage and seaweed extract were used in solution at a $0.50{ }^{\circ} \operatorname{Brix}(0.42 \% \mathrm{w} / \mathrm{v})$ concentration to replace the mixing water. The proportions of the concrete mixes and their fresh state properties are shown in Table 3 .

\subsubsection{Preparation and curing of specimens}

Cylindrical specimens with $100 \mathrm{~mm}$ diameter and $200 \mathrm{~mm}$ height were cast from each mix. The specimens were cast in triplicate for a total of 240 cylinders. All specimens were removed from the mold after one day and moist-cured for 0 and 28 days. The specimens with 0 days of moist curing $\left({ }^{\circ} \mathrm{C}\right)$ were kept in a room at ambient temperature and relative humidity. The specimens moist-cured for 28 days $\left(28^{\circ} \mathrm{C}\right)$ were kept at $23 \pm 3{ }^{\circ} \mathrm{C}$ and $95 \% \mathrm{RH}$. After curing, all of the specimens were stored at ambient temperature and relative humidity.

\subsection{Hardened concrete testing}

The tests carried out included determination of compressive strength (96 cylinders), capillary water absorption (48 cylinders), rapid chloride permeability (48 cylinders), accelerated chloride diffusion (48 half cylinders), and accelerated carbonation (48 half cylinders). The tests were undertaken at later ages (60 and 120 days of age) because of the retarding effect on the development of mechanical properties reported in the literature when using cactus mucilage $(11,13)$.

TABLE 3. Ingredient proportions for the production of $1 \mathrm{~m}^{3}$ concrete mix and fresh state properties

\begin{tabular}{lcccccccc}
\hline Concrete Mixture & \multicolumn{2}{c}{ Control } & \multicolumn{2}{c}{$\mathbf{M}^{\mathbf{a}}$} & \multicolumn{3}{c}{$\mathbf{A}^{\mathbf{b}}$} & \multicolumn{3}{c}{$\mathbf{M}^{\mathbf{c}} \mathbf{A}^{\mathbf{c}}$} \\
\hline w/c ratio & 0.30 & 0.60 & 0.30 & 0.60 & 0.30 & 0.60 & 0.30 & 0.60 \\
Coarse aggregate $(\mathrm{kg})$ & 974 & 860 & 974 & 860 & 974 & 860 & 974 & 860 \\
Fine aggregate $(\mathrm{kg})$ & 672 & 797 & 672 & 797 & 672 & 797 & 672 & 797 \\
Cement $(\mathrm{kg})$ & 519 & 345 & 519 & 345 & 519 & 345 & 519 & 345 \\
Water $(\mathrm{kg})$ & 157 & 207 & 157 & 207 & 157 & 207 & 157 & 207 \\
Superplasticizer $(\mathrm{mL})$ & 4671 & & 4671 & & 4671 & & 4671 & \\
Slump $(\mathrm{cm})$ & 20 & 16.2 & 21 & 19 & 21 & 14 & 21 & 15.4 \\
Air content $(\%)$ & 1.5 & 1.5 & 1.9 & 2.4 & 2.3 & 2.5 & 2.1 & 2.1 \\
Temperature $\left({ }^{\circ} \mathrm{C}\right)$ & 24 & 24.5 & 24.5 & 23.5 & 23.5 & 22 & 22 & 24 \\
Volumetric weight $\left(\mathrm{kg} / \mathrm{m}^{3}\right)$ & 2331 & 2260 & 2341 & 2245 & 2331 & 2227 & 2349 & 2231 \\
\hline
\end{tabular}

${ }^{\mathrm{a}} \mathrm{M}$ : containing cactus mucilage solution

${ }^{\mathrm{b}} \mathrm{A}$ : containing seaweed extract solution.

${ }^{\mathrm{c}} \mathrm{M}-\mathrm{A}$ : containing both cactus mucilage and seaweed extract solutions. 


\subsubsection{Compressive strength}

The compressive strength was determined at 60 and 120 days using an ELVEC hydraulic testing machine with a capacity of 120 tons in accordance with the testing procedure described in the ASTM C 39/C 39M standard (40).

\subsubsection{Capillary water absorption}

The specimens were cut into two halves and dried in an oven at $105^{\circ} \mathrm{C}$ until a weight difference of less than $0.5 \%$ between two measurements at 24 hour intervals was obtained. Epoxy resin was applied only to the curved surface and kept for 24 hours at ambient temperature to allow the resin to harden. The sorptivity test consisted of placing the specimens in plastic containers with supports under the bottom surface to allow for the free capillary absorption of water (41). The water level was maintained at $2-5 \mathrm{~mm}$ above the bottom surface of the specimen (Figure 1). The mass gained was measured at 5, 10, 15, 20, 30, 60, 120, 240, 480, 1440 and 2880 minutes. Each time the specimen was removed from the container, it was wiped with a moist cloth to remove excess water and then weighed using a digital scale with $0.01 \mathrm{~g}$ precision. The sorptivity was calculated with the data obtained from up to $8 \mathrm{~h}$ of testing where the data show a linear relationship (41). In addition, the volume of permeable pores was determined according to the standard ASTM C 642 (42).

\subsubsection{Rapid chloride permeability test (RCPT) and accelerated chloride diffusion}

2.5.3.1. Rapid chloride permeability test. The rapid chlorine permeability test was performed on concrete specimens measuring $100 \mathrm{~mm}$ in diameter and $50 \mathrm{~mm}$ in length, in accordance with the ASTM C 1202 standards (43). A PROOVE'it equipment from Germann Instruments was used.

2.5.3.2. Accelerated chloride diffusion. The accelerated chloride diffusion test was performed on 120-day-old concrete specimens after 35 days of exposure to a $16.5 \%$ sodium chloride solution, in

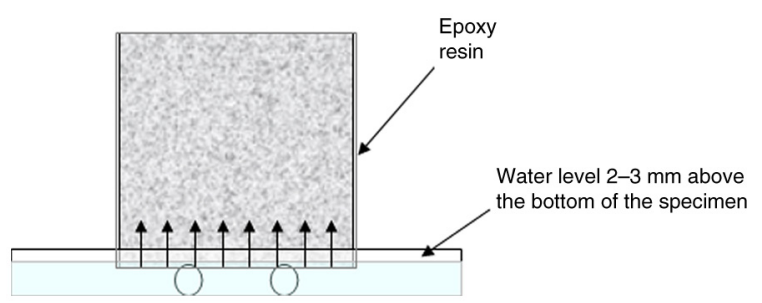

FIGURE 1. Setup for the capillary water absorption test. accordance with the Nordtest Method NT BUILD 443 (44). After the exposure period, chloride ion concentrations in powder extracted from layers $2 \mathrm{~mm}$ thick were determined by chemical titration. The effective chloride diffusion coefficient and the surface concentration were obtained by adjusting the experimental data to the solution of Fick's second law (45).

\subsubsection{Accelerated carbonation}

Accelerated carbonation tests were performed on 180-day-old concrete specimens in a carbonation chamber. The flat sides of the specimen were sealed with epoxy resin, exposing the curved surface to $4.4 \% \mathrm{CO}_{2}, 60 \% \pm 5 \% \mathrm{RH}$ and $23 \pm 2{ }^{\circ} \mathrm{C}$ for 120 days. To determine the carbonation depth, a 1\% alcoholphenolphthalein solution was sprayed on the broken specimen as a $\mathrm{pH}$ indicator. The carbonation depth was reported as the average of eight readings across the diameter of the cylinder and the carbonation coefficient was then determined.

\section{RESULTS AND DISCUSSION}

\subsection{Rheological measurements in aqueous solutions containing organic admixtures}

Cactus mucilage and seaweed extract solutions behaved like shear thinning fluids, meaning that their viscosity decreases as the shear rate increases. In this case, the curves obtained were fitted to the Herschel-Bulkley model given by equation [1]:

$$
\tau=\tau_{0}+k^{*} \gamma^{\mathrm{n}}
$$

where $\tau_{0}$ is the yield stress $(\mathrm{Pa}), k$ is the consistency index $\left(\mathrm{Pa} \mathrm{s}^{\mathrm{n}}\right), \gamma$ is the shear rate $\left(\mathrm{s}^{-1}\right)$, and $n$ is the fluid behavior index.

Figure 2 shows the plots for the consistency index and the fluid behavior index versus the extract

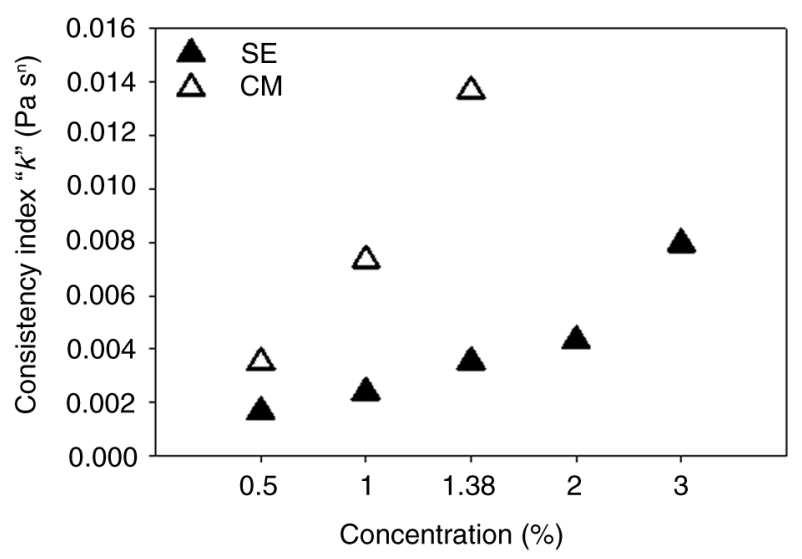

FIGURE 2. Consistency index versus extract concentration. 
concentration. The value of $k$ increases with increasing extract concentration, especially with cactus mucilage. Considering that the dynamic viscosity value of pure water is $0.89 \times 10^{-3} \mathrm{~Pa} \mathrm{~s}\left(\right.$ at $25^{\circ} \mathrm{C}$ ), the viscosity of the solutions containing cactus mucilage and seaweed extract increased 15 and 19 times, respectively, when tested at a shear rate of $1 \mathrm{~s}^{-1}$.

According to Bentz et al. (46), it is possible to double the service life of concrete by doubling the viscosity of the pore solution. The use of viscosityenhancing admixtures (VEAs) may increase the viscosity of the pore solution and, as a result, decrease diffusion (47). Leon-Martinez et al. (14) obtained good results employing cactus mucilage and marine brown algae extract as a substitute for commercial VEA in the development of self-consolidating concrete. Therefore, it is possible that the viscosity of the pore solution of hardened concrete containing these admixtures could be higher compared to those without any VEA.

The pore solution from cement pastes or mortars with w/c ratios of 0.50 has an $\mathrm{OH}^{-}$concentration of approximately $0.30-0.45 \mathrm{M}$ (48). The equivalent value of $\mathrm{OH}^{-}$from a solution of cactus mucilage $(1.38 \% \mathrm{w} / \mathrm{v})$ saturated with calcium hydroxide is $0.25 \mathrm{M}$. Figure 3 shows that the viscosities for a shear rate of $1 \mathrm{~s}^{-1}$ are approximately 26 and 34 times higher for solutions containing $\mathrm{Ca}(\mathrm{OH})_{2}$ at $0.25 \mathrm{M}$ and $1.0 \mathrm{M}$, respectively, compared to the viscosity of water. Assuming these viscosities for the pore solution, the ionic diffusion in hardened concrete should be reduced. During the formation of the porous structure, one part of the admixture could be adsorbed on the surface of the pores and the other remains in the pore solution. As hydration reduces the amount of porosity, it is hypothesized that the concentration of these polymers in the pore solution should be higher than the initial concentration.

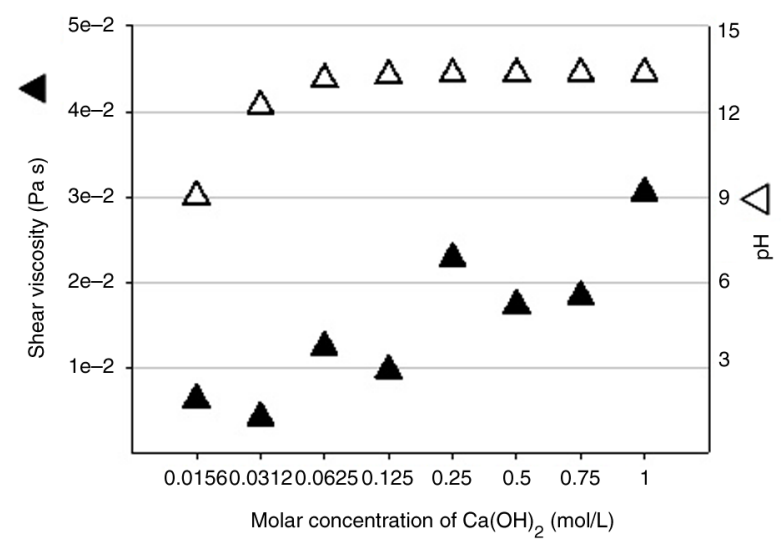

Figure 3. Effect of the calcium hydroxide concentration on the viscosity of cactus mucilage $(\mathrm{CM})$ dispersions at $1.38 \%(\mathrm{w} / \mathrm{v})$ and $\mathrm{pH}$.

\subsection{Degree of hydration and pore size distribution}

Figure 4 shows that the degree of hydration of cement pastes (w/c of 0.30 ) at 28 days containing both organic additions was higher compared to the control. In addition, the moist curing increased the degree of hydration as expected. At 120 days and 1 year, only moist-cured cement pastes containing the organic admixtures had a higher degree of hydration with respect to the control. In Figure 5, cement pastes with a w/c ratio of 0.60 containing mucilage at $1.82 \%(\mathrm{M} 1.82)$ showed severe retardation of the cement hydration at the age of 28 days. This effect could be linked to adsorption of the polymers on the first hydrates, forming a less permeable coating that delayed the formation of $\mathrm{CSH}$ and portlandite (49). In cement pastes containing seaweed extract, the degree of hydration increases with increasing concentration of the polymer. The type of curing had a marginal effect, indicating that the polymer probably served as internal curing (21). At 120 days and 1 year, the degree of hydration was similar for all concentrations. To fully understand the effect of these admixtures on the hydration process, research is in progress and the results will be published in the near future. The degrees of hydration obtained are consistent with the results from the compressive strength testing (Section 3.3). Both the compressive strength and the permeability of cement pastes are linked to capillary porosity, which depend on the w/c ratio and the degree of hydration (50).

The results of the NMR studies on cement pastes, the organic admixtures, and hydration for 1 year under sealed curing are shown in Figure 6. Before carrying out the testing, the samples were saturated with distilled water to reveal all of the pores present in the cement paste. The short $T_{2}$ component is related to small capillary pores, and the long $\mathrm{T}_{2}$ component is related to large capillary pores (51); therefore, the short $\mathrm{T}_{2}$ amplitude/long $\mathrm{T}_{2}$ amplitude ratio $>1$ indicates a higher amount of fine pores. For instance, the cement paste with a w/c of 0.30 and $0.50 \%$ organic admixtures possesses a higher amount of fine pores compared to the control. In cement pastes with a w/c of 0.60 containing cactus mucilage, the amount of fine pores with respect to the control decreases with increasing concentration of the polymer. Conversely, the seaweed extract has a higher amount of fine pores with increasing concentration of seaweed extract, only decreasing when the concentration is $1.82 \%$. The use of both admixtures increased the air content in the fresh concrete by approximately $1 \%$ above the control (Table 3 ), which may play a minor role in strength and permeability.

\subsection{Compressive strength}

Figure 7 presents the compressive strength results at the ages of 60 and 120 days for the concrete mixes studied. The organic admixtures did not 

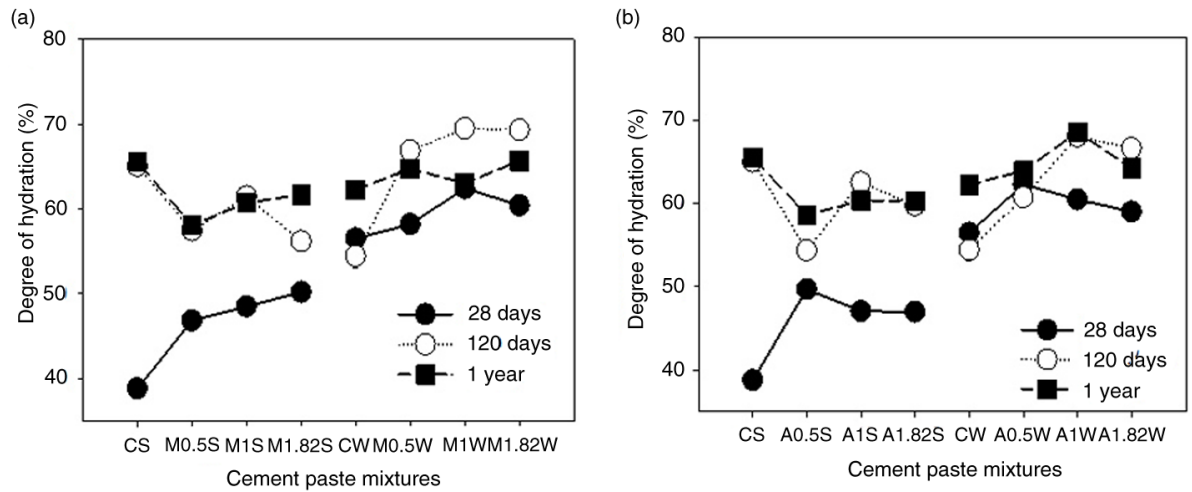

FIgURE 4. Degree of hydration of cement pastes with $w / c$ ratio $=0.30$, a) cactus mucilage, and b) seaweed extract. $\mathrm{S}=$ sealed curing, $\mathrm{W}=$ moist curing.
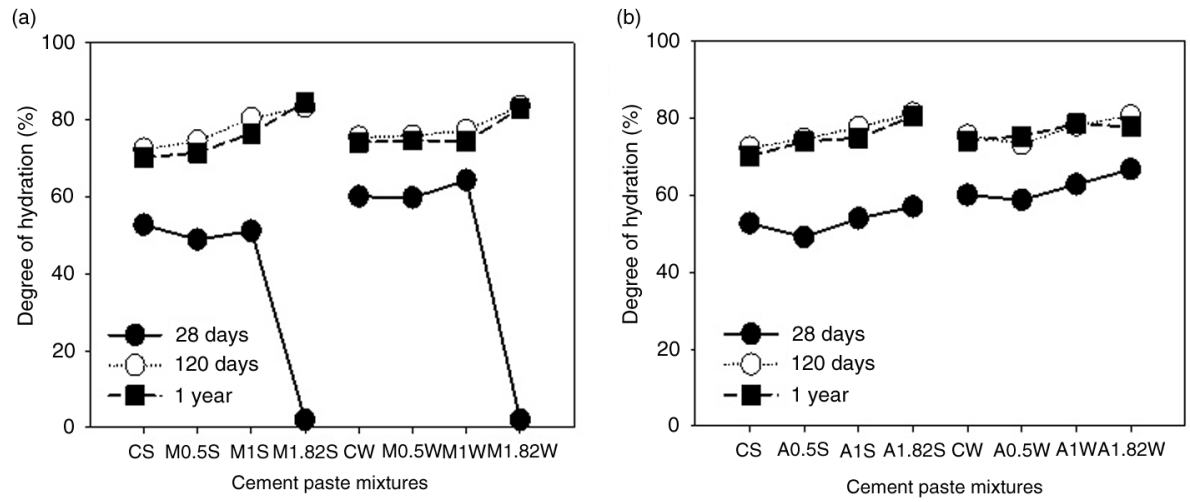

Figure 5. Degree of hydration of cement pastes with w/c ratio=0.60, a) cactus mucilage, and $b$ ) seaweed extract. $\mathrm{S}=$ sealed curing, $\mathrm{W}=$ moist curing.
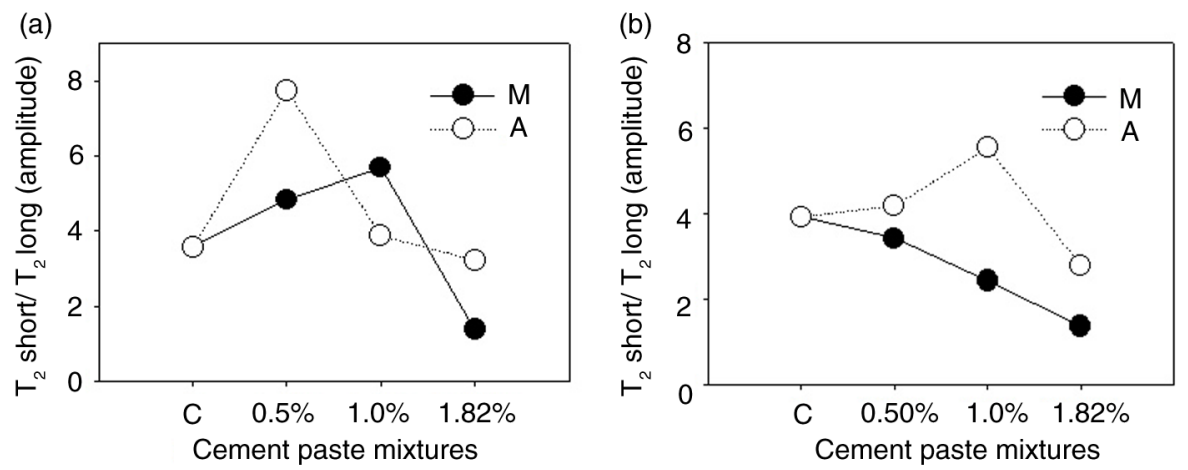

Figure 6. Amplitude of short $\mathrm{T}_{2} /$ Amplitude of long $\mathrm{T}_{2}$ ratio of cement pastes. a) w/c ratio of 0.30 and b) w/c of 0.60 .

significantly affect the compressive strength compared to the control, especially in the concrete mixes with a w/c ratio of 0.30 . Only in the case of concrete with a w/c ratio of 0.60 (Figure $7 \mathrm{~b}$ ) for zero days moist curing and containing both cactus mucilage and seaweed extract, was a slight increase $(20 \%)$ in compressive strength at 120 days observed with respect to the control. This result may be linked to the water holding capacity of these admixtures that make it available when needed to support further cement hydration $(21,52)$.

A retrogression of the concrete strength from 60 to 120 days was also observed, especially in the control mix with a w/c of 0.30 , moist-cured. The specimens 

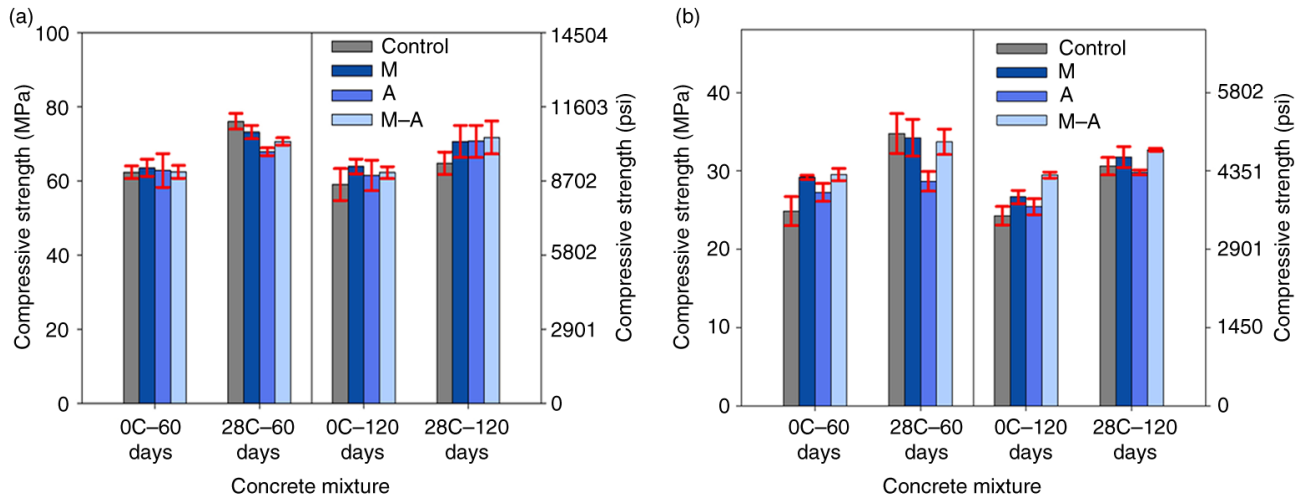

FIGURE 7. Compressive strength of concrete specimens at 60 and 120 days old for a) $\mathrm{w} / \mathrm{c}=0.30$ and $\mathrm{b}$ ) $\mathrm{w} / \mathrm{c}=0.60$. The error bars represent one standard deviation.

that were moist-cured containing the organic admixtures do not show a significant strength reduction, perhaps because of the water holding capacity of the admixtures that reduce drying shrinkage-related tensile stresses. De Larrard and Aitcin (53) regarded the strength retrogression as an effect caused by the moisture gradients developed when concrete dries out in the long term generating tensile stresses on the surface and additional compressive stresses in the inner concrete, thus appearing as a strength reduction of the material. The moisture gradients will be higher in low w/c ratio concrete that has a lower permeability, and therefore, the strength retrogression will be higher.

The results from the present study are contrary to those obtained by Hernandez-Zaragoza et al. (12) who used lyophilized cactus gum in Portland cement mortar with a w/c ratio of 0.60 . They claim to have increased compressive strength by up to $65 \%$ at three days compared to the control. The behavior observed by those authors is not clear because the compressive strength reported increases and decreases in an alternating fashion with increasing cactus gum concentration without any definite trend. Furthermore, the addition of cactus mucilage increases the setting times and significantly delays cement hydration (13). Therefore, higher compressive strength at only three days with respect to the control cannot be expected and it is not feasible to make strong conclusions from their data. Chandra et al. (11) reported increases in compressive strength of $6 \%$ and $12 \%$ in mortar containing $50 \%$ and $100 \%$ of cactus mucilage solution replacing the mixing water compared to the control at 90 days of age. Before this age, the compressive strength of concrete containing cactus mucilage was always lower than the control.

\subsection{Capillary water absorption}

Figure 8 presents the sorptivity and the permeable porosity results of concretes with a w/c of 0.30 . Figure $8 \mathrm{a}$ shows that mixes containing cactus mucilage and seaweed extract have slightly lower sorptivity values than the control. The combination of cactus mucilage and seaweed extract did not influence sorptivity. The reduction in water absorption is explained by the lower permeable porosity shown
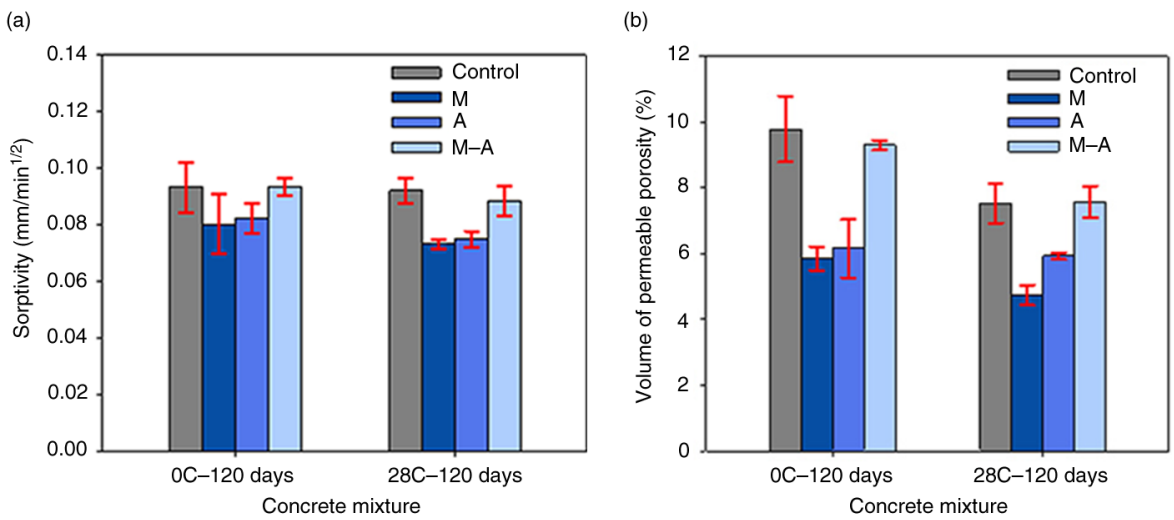

FIGURE 8. a) Sorptivity and b) Volume of permeable porosity of concrete with $\mathrm{w} / \mathrm{c}$ ratio $=0.30$ and 120 days old. The error bars indicate one standard deviation. 


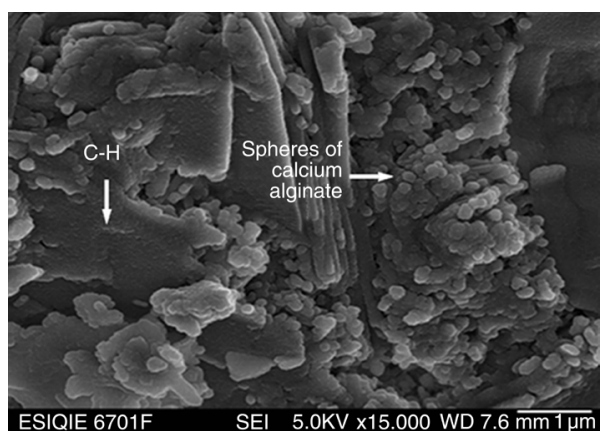

FIGURE 9. Microphotograph of 2 years old concrete, w/c ratio $=0.30$ containing seaweed extract. Magnification $15000 \mathrm{X}$.

in Figure 8b. Changes in the pore size distribution in cement pastes containing the organic additions, as indicated by the NMR results shown in Figure 6, where the short $\mathrm{T}_{2}$ component is related to small capillary pores and the long $\mathrm{T}_{2}$ component is related to large capillary pores (51). Hughes (54) proposes an equation that considers the capillary flow as directly linked to the pore radius and the tortuosity of the system. Therefore, in a system of finer pores and higher tortuosity, the capillary flow should be lower compared to systems of larger and more connected pores. Chandra et al. (11) suggests that the reduction in water absorption when cactus mucilage is added to mortars is because a film formed by the admixture and the calcium complexes formed during the interaction between the cactus mucilage and the divalent calcium ions, seals the pores. Similarly, the alginate found in the seaweed extract, reacts with calcium ions to form spheres of calcium alginate (Figure 9). Other studies have shown similar morphology of the calcium alginate spheres (19). Furthermore, the type of curing had no significant effect. These results are in agreement with those reported by RamírezArellanes et al. (13) and Caballero (55), which indicated that the use of cactus mucilage reduces the capillary water absorption of concrete with w/c ratios of 0.30 that were moist-cured for 0 and seven days.

Figure 10 shows the sorptivity and permeable porosity of the concretes with a w/c ratio of 0.60 . In this case, concretes containing organic admixtures, especially concrete containing seaweed extract, have higher sorptivity values than those of the control. Again, the type of curing did not have any significant effect on the results. The higher water absorption capacity of the concretes with organic admixtures is associated with the presence of nonpolar protein segments, which make these admixtures act as air entraining agents that increase the porosity compared to the control mix (Figure 10b) (11). This effect is exacerbated in this mix because of the higher polymer/cement ratio compared to concrete with a w/c ratio of 0.30 .

\subsection{Rapid chloride permeability and accelerated chloride diffusion}

\subsubsection{Rapid chloride permeability}

The effect of organic admixtures on the rapid chloride permeability test in concretes with a w/c ratio of 0.30 and 0.60 is illustrated in Figure 11. In concrete with a w/c ratio of 0.30 (Figure 11a), the charge passed was reduced in concretes containing organic admixtures compared to the control for both types of curing and at both testing ages. At 120 days of age, the values of the charge passed in the control sample, in accordance with the ASTM C 1202 standard, correspond to moderate chloride permeability concrete, whereas concretes containing organic admixtures correspond to low permeability concretes. In general, the trend seems to follow the permeable porosity (Figure $8 \mathrm{~b}$ ), which was affected by the possible formation of complexes of calcium and the reduction of the size of calcium hydroxide crystals (11) as well as by the formation of small
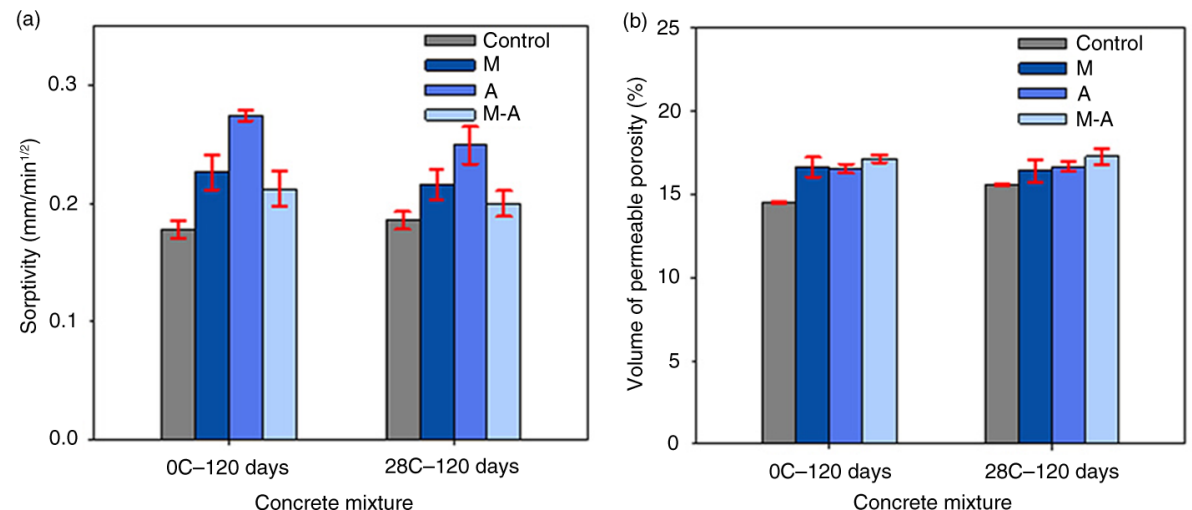

FIGURE 10 . a) Sorptivity and b) Volume of permeable porosity of concrete with $\mathrm{w} / \mathrm{c}$ ratio $=0.60,120$ days old. The error bars indicate one standard deviation. 

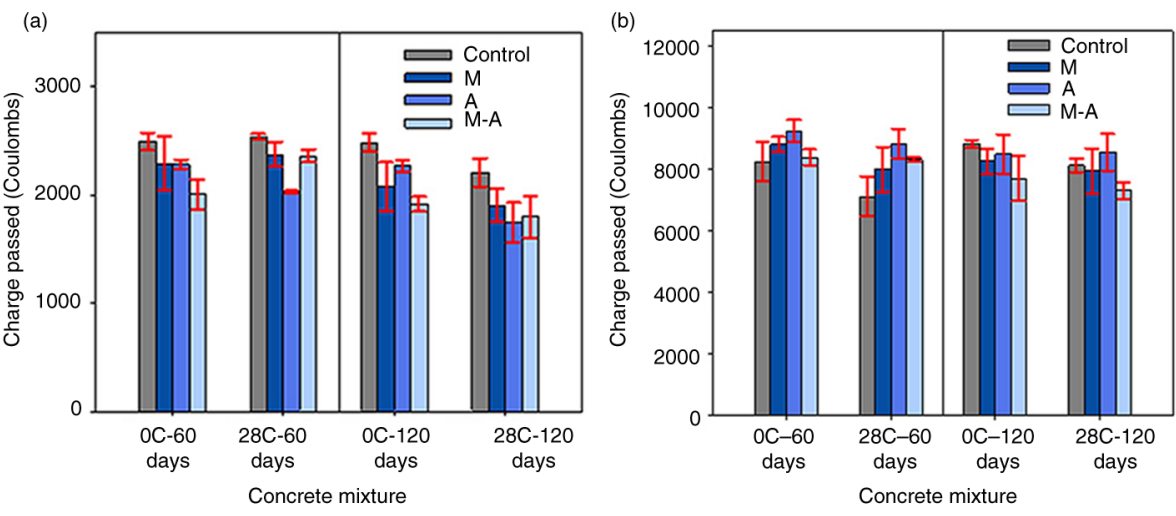

FIGURE 11. Charge passed (Coulombs) in concrete specimens at 60 and 120 days old, a) $\mathrm{w} / \mathrm{c}$ ratio $=0.30$ and $\mathrm{b}$ ) $\mathrm{w} / \mathrm{c}$ ratio $=0.60$. The error bars indicate one standard deviation.

spheres of calcium alginate (Figure 9) when the seaweed extract containing alginic acid reacts with calcium ions (19), thus reducing the permeable porosity.

In contrast, at 60 days of age, concretes with a w/c ratio of 0.60 containing the organic admixtures had a higher charge passed compared to the control (Figure 11b). At 120 days, the charge passed is reduced only in specimens containing both cactus mucilage and seaweed extract. Other specimens had similar performance to the control. The permeability to chloride ions in all of the mixes at both testing ages and types of curing is considered high in accordance to the ASTM C 1202 standard.

Figure 12 indicates a linear relationship between the charge passed from the rapid chloride permeability test and the compressive strength of concretes with w/c ratios of 0.30 and 0.60 at 120 days old. In both cases, high values of compressive strength correspond to low values of charge passed, and vice versa. In concretes with a w/c ratio of 0.30 , the determination coefficients $\left(r^{2}\right)$ were lower compared to those obtained in concretes with a w/c ratio of 0.60 .

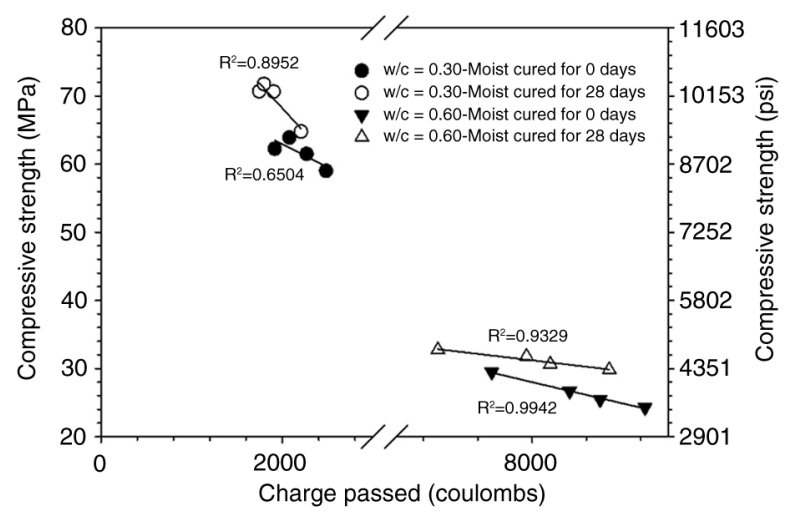

FIGURE 12. Relationship between the charge passed and the compressive strength of concretes $\mathrm{w} / \mathrm{c}$ ratio $=0.30$ and 0.60 , at 120 days of age.
This may be explained by taking into account that admixtures in concretes with a w/c ratio of $0.30 \mathrm{did}$ not have as significant of an effect on the compressive strength as they did on the rapid chloride permeability test. Conversely, the admixtures had an effect on both the compressive strength and the chloride ion permeability of concretes with a w/c ratio of 0.60 .

\subsubsection{Accelerated chloride ion diffusion}

The results of the accelerated chloride diffusion tests in concretes with a w/c ratio of 0.30 and 0.60 are presented in Figure 13. Concretes with a w/c ratio of 0.30 (Figure 13a) containing organic admixtures, especially cactus mucilage, had lower diffusion coefficients compared to the control. Figure 13b (concrete with a w/c of 0.60 ) also indicates lower chloride ion diffusion coefficients in mixes containing the organic admixtures compared to the control. In this case, concretes containing cactus mucilage/ seaweed extract exhibited the lowest values. For both w/c ratios the curing had no significant effect on the results.

In concretes with a w/c ratio of 0.30 containing the admixtures, the reduction in the diffusion coefficients suggests that they are less permeable than the control, as further indicated by the capillary absorption and porosity results. In concretes with a w/c ratio of 0.60 containing organic admixtures, the reduction in the diffusion coefficients can be attributed to the increased viscosity of the pore solution caused by the presence of polysaccharides with high molecular weight in these admixtures. In these concretes, the viscosity of the pore solution should be increased by a higher amount of polysaccharides compared to the concrete with a w/c ratio of 0.30 .

The Stokes-Einstein equation establishes an inverse relation between the diffusion coefficient and the viscosity of the solution. The presence of molecules that interact with water and increase its viscosity can 
(a)

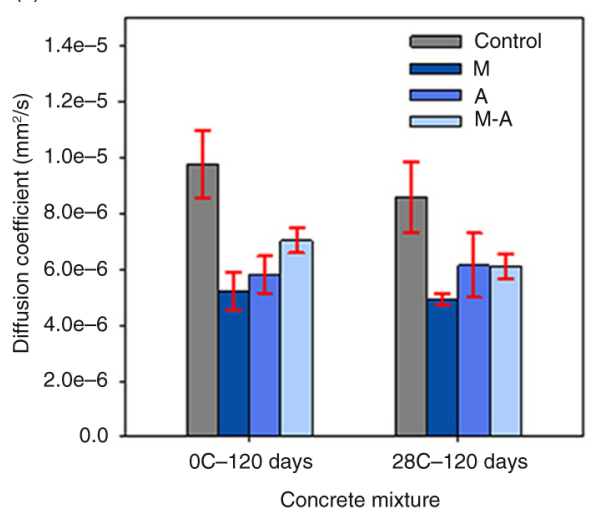

(b)

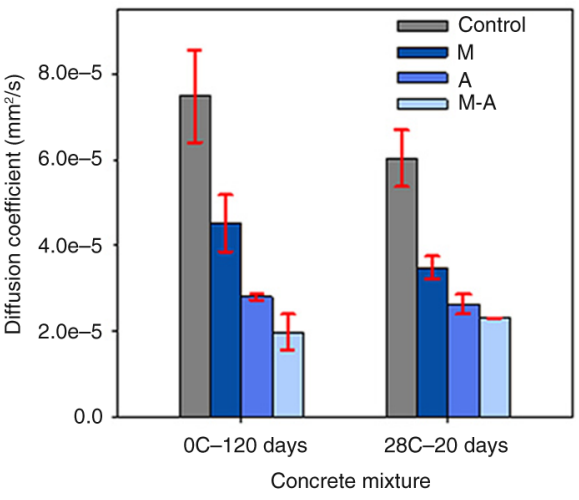

FIGURE 13. Diffusion coefficients of $\mathrm{Cl}^{-}$in concrete at 120 days, a) w/c ratio $=0.30$ and b) $w / c$ ratio $=0.60$. The error bars represent one standard deviation.

also serve as physical barriers that reduce the diffusion coefficient (47). Using the experimental diffusion coefficients for the concretes studied, the apparent viscosity of the pore solution was then calculated. For instance, the concrete with a w/c ratio of 0.30 containing cactus mucilage had a chloride diffusion coefficient of $4.93 \times 10^{-6} \mathrm{~mm}^{2} / \mathrm{s}$, and the concrete containing seaweed extract had a diffusion coefficient of $5.81 \times 10^{-6} \mathrm{~mm}^{2} / \mathrm{s}$. The calculated apparent viscosities of the pore solution are $284 \mathrm{cP}$ and $241 \mathrm{cP}$, respectively. These values of viscosity are in the same order of magnitude as those determined experimentally by Poinot et al. (56), who extracted pore solution from mortars containing viscosity-enhancing admixtures. Performing the same calculation to obtain the viscosity of the pore solution in concrete without any organic admixtures gives a value of approximately $163 \mathrm{cP}$; for the concrete with a w/c of 0.60 , it is estimated as $23 \mathrm{cP}$. Trachtenberg and Mayer (52) obtained values of reduced viscosity 250 times higher than that of water from a cactus mucilage solution containing $1 \mathrm{M}$ of $\mathrm{CaCl}_{2}$ in water and an acid solution. In an alkaline cactus mucilage solution ( $\mathrm{pH}$ 9.8) containing $0.1 \mathrm{M} \mathrm{CaCl}_{2}$, increases in viscosity up to 750 times higher than water were observed. These calculations suggest that it is possible that the viscosity of a pore solution containing the organic admixtures may contribute to an approximately $42 \%$ reduction in the diffusion coefficient, which is consistent with the results shown in Figure 13. The same calculations were performed in concretes with a w/c ratio of 0.60 containing cactus mucilage and seaweed extract. The chloride ion diffusion coefficients were $3.49 \times 10^{-5} \mathrm{~mm}^{2} / \mathrm{s}$ and $2.63 \times 10^{-5} \mathrm{~mm}^{2} / \mathrm{s}$ for the concrete mixes containing cactus mucilage and seaweed extract, respectively. The apparent viscosities are estimated as $40 \mathrm{cP}$ and $53 \mathrm{cP}$, respectively, and the reduction of the chloride diffusion coefficient is approximately $56 \%$.

\subsection{Carbonation}

Figure 14a shows the carbonation results of concretes with a w/c ratio of 0.30 . Mixes containing cactus mucilage and seaweed extract and moist-cured for 0 days exhibit reduced carbonation front with respect to both the control and the combination of mucilage and seaweed extract. This combination of cactus mucilage and seaweed extract had an adverse effect, increasing the carbonation front even with respect to the control. These results are related to the lower porosity and lower sorptivity of these mixes (see the Capillary water absorption section). In the case of mixes moist-cured for 28 days, those containing only seaweed extract showed carbonation. This could be because the alginate in the seaweed extract forms insoluble chemical compounds with divalent ions such as $\mathrm{Ca}^{2+}(19)$. This reduces the availability of $\mathrm{Ca}(\mathrm{OH})_{2}$ necessary for the formation of $\mathrm{CaCO}_{3}$, allowing for the increased penetration of $\mathrm{CO}_{2}$

In concrete with a w/c ratio of 0.60 (Figure 14b) and moist-cured for 0 days, the highest reduction in the carbonation front was obtained in mixes containing cactus mucilage and those containing a combination of cactus mucilage and seaweed extract. In concretes containing only seaweed extract, the carbonation depth was comparable to that of the control. The same performance occurred in concretes that were moist-cured for 28 days. The curing significantly affected the control mix and the mixes containing seaweed extract. An explanation for the lower carbonation depth observed when cactus mucilage is used, may be linked to its capacity to retain water and to form calcium complexes with calcium hydroxide (11). In the first case, the higher water content permits dissolution of $\mathrm{Ca}(\mathrm{OH})_{2}$ that reacts with $\mathrm{CO}_{2}$ to form more $\mathrm{CaCO}_{3}$, whereas the calcium complexes formed may act like pore sealants that reduce the permeability to $\mathrm{CO}_{2}$. Studies with lime mortar have shown the opposite performance, 
(a)

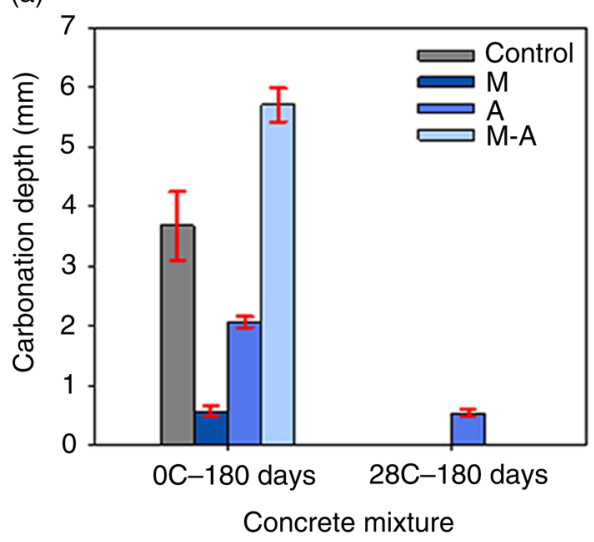

(b)

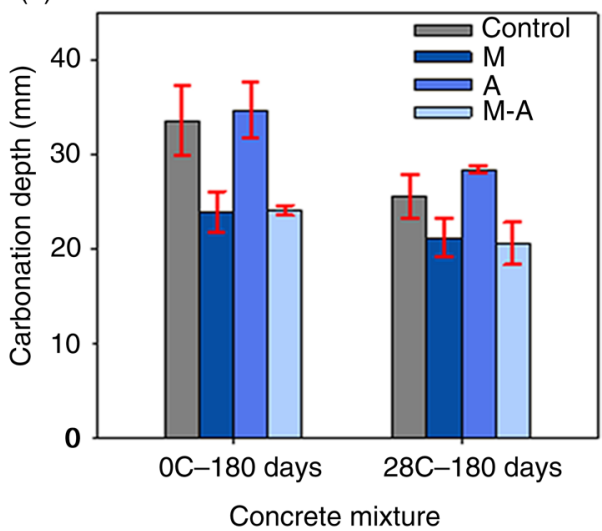

FIgURE 14. Carbonation depth in concrete at 180 days, a) w/c ratio $=0.30$ and b) $w / c$ ratio $=0.60$. The error bars represent one standard deviation.

where cactus mucilage increased the carbonation depth with respect to the control (57).

To calculate the carbonation coefficient that would be obtained under normal ambient conditions, based on the carbonation coefficient obtained in the accelerated test of this investigation, equation [2] was used (58):

$$
\frac{K_{a c c}}{K_{a m b}}=\frac{\sqrt{C 1_{a c c}}}{\sqrt{C 2_{a m b}}}
$$

where

$\mathrm{K}_{\mathrm{acc}}=$ accelerated test carbonation coefficient $\left(\mathrm{mm} /\right.$ days $\left.^{1 / 2}\right)$

$\mathrm{K}_{\mathrm{amb}}=$ ambient carbonation coefficient $\left(\mathrm{mm} /\right.$ days $^{1 / 2}$ ) $\mathrm{Cl}_{\text {acc }}=$ concentration of $\mathrm{CO}_{2}$ in accelerated test $(4.40 \%)$ $\mathrm{C} 2_{\mathrm{amb}}=$ ambient $\mathrm{CO}_{2}$ concentration $(0.04 \%)$.

Table 4 shows the time required to reach a carbonation front at a $25 \mathrm{~mm}$ reinforcement level for each mix type. The results obtained in concretes containing cactus mucilage with a w/c ratio of 0.60 showed significant increases in time. In the case of concretes with a w/c ratio of 0.30 , the carbonation front will not reach the reinforcing steel in a lifespan of 60 years.

\section{CONCLUSIONS}

Based on the results of this experimental research, the following conclusions are drawn:

1. Addition of cactus mucilage and seaweed extract to concrete produced distinct effects on the mechanical properties and durability depending on the water to cement ratio. In the case of a low w/c ratio, the permeable porosity decreased because of the water holding capacity of the polymers, which provided additional moisture for further cement hydration. In concrete with high w/c ratio, the additional water did not improve hydration because there was already enough water for hydration, and the porosity increased as a result of the retardation effect on cement hydration and the subsequent drying. Those changes in porosity marginally affected compressive strength, being the most noticeable in concrete with a w/c ratio of 0.60 and 0 days moist-cured, where the combination of cactus mucilage and seaweed extract increased the strength at 120 days by $20 \%$ with respect to the control.

2. Regarding durability, the capillary water absorption and the rapid chloride permeability were marginally influenced by the permeable porosity produced by the use of the admixtures, being lower in concrete with a low w/c ratio and higher

TABLE 4. Prediction of time required to carbonate $25.4 \mathrm{~mm}$ (1 in.) of concrete

\begin{tabular}{lccc}
\hline \multicolumn{1}{c}{ Mixture } & $\mathbf{K}_{\text {acc }}\left(\mathbf{m m} / \mathbf{d a y s}^{1 / 2}\right)$ & $\mathbf{K}_{\text {amb }}\left(\mathbf{m m} / \mathbf{d a y s} \mathbf{s}^{1 / 2}\right)$ & Years \\
\hline 06-0CC & 3.07 & 0.29 & 20.0 \\
06-0CM & 2.19 & 0.21 & 39.38 \\
06-0CA & 3.17 & 0.30 & 18.72 \\
06-0CMA & 2.21 & 0.21 & 38.70 \\
06-28CC & 2.34 & 0.22 & 34.42 \\
06-28CM & 1.94 & 0.18 & 50.25 \\
06-28CA & 2.59 & 0.25 & 27.99 \\
06-28CMA & 1.88 & 0.18 & 53.13 \\
03-0CC & 0.33 & 0.03 & $>60$ \\
03-0CM & 0.05 & 0.00 & $>60$ \\
03-0CA & 0.19 & 0.02 & $>60$ \\
03-0CMA & 0.52 & 0.05 & $>60$ \\
03-28CC & - & - & $>60$ \\
03-28CM & - & - & $>60$ \\
03-28CA & 0.05 & 0.00 & $>60$ \\
03-28CMA & - & - & $>60$ \\
\hline
\end{tabular}


in concrete with a high w/c ratio, compared to the control mixes. The chloride ion diffusion coefficients were clearly reduced by the use of the cactus mucilage and seaweed extract in both w/c ratios and curing types compared to the control mix. Combinations of the lower porosity and/ or changes in the properties of the pore solution (viscosity) could explain these results. The carbonation depth was decreased in concrete containing cactus mucilage compared to the control mixes as a result of the decreased permeable porosity and increased viscosity.

\section{ACKNOWLEDGEMENTS}

Prisciliano Cano would like to thank the Consejo Nacional de Ciencia y Tecnologia (Conacyt) of Mexico for funding the project ID code CB 103763 , and the SIP of the Instituto Politecnico Nacional of Mexico for funding the project ID code 20140613. Eddisson Francisco Hernandez would like to thank CONACYT for his PhD scholarship and IPN for the PIFI scholarship. The authors acknowledge M. Sc. Frank Manuel León-Martinez for useful discussions on the rheology of aqueous solutions and cement pastes.

\section{REFERENCES}

1. Mehta, P.K. (1997) Durability- Critical issues for the future. Concrete International. 19 [7], 27-33.

2. Glasser, F.P.; Marchand, J.; and Samson, E. (2008) Durability of concrete- degradation phenomena involving detrimental chemical reactions. Cem. Concr. Res. 38 [2], 226-246. http:// dx.doi.org/10.1016/j.cemconres.2007.09.015.

3. Neville, A. (1995) Chloride attack of reinforced concrete: an overview. Mater Struct. 28 [2], 63-70. http://dx.doi.org/ 10.1007/BF02473172.

4. Mehta, P.K.; Gerwick, B.C. (1982) Cracking-corrosion interaction in concrete exposed to marine environment. Concrete International. 4 [10], 45-51.

5. Neville, A.M. (1995) Properties of concrete, fourth edition, Pearson Education Limited, England.

6. Aïtcin, P.C. (2003) The durability characteristics of high performance concrete: a review. Cem. Concr. Comp. 25 [4-5], 409-420. http://dx.doi.org/10.1016/S0958-9465(02)00081-1.

7. Mehta, P.K. (1999) Advancements in Concrete Technology. Concrete International. 21 [6], 69-76.

8. Ann, Y.K.; Jung, H.S.; Kim, H.S; Kim, S.S.; Moon, H.Y. (2006) Effect of calcium nitrite-based corrosion inhibitor in preventing corrosion of embedded steel in concrete. Cem. Concr. Res. 36 [3], 530-535. http://dx.doi.org/10.1016/j. cemconres.2005.09.003

9. Wu, X.; Chou, N.; Lupher, D.; Davis, L.C. (1998) Benzotriazoles: Toxicity and Degradation. Proceedings, The $13^{\text {th }}$ Annual conference on hazardous waste research, Snowbird, Utah. Project no. 94-27, 374-382.

10. Cárdenas, A.; Arguelles, W.M.; Goycoolea F.M. (1998) On possible role of Opuntia Ficus Indica mucilage in lime mortar performance in the protection of historical buildings. J. Prof. Assoc. Cactus. 3, 1-8, Online at http:// jpacd.org/downloads/Vol3/RAC_4.pdf.

11. Chandra, S.; Eklund, L.; Villarreal R.R. (1998) Use of cactus in mortars and concrete. Cement and Concrete. 28 [1], 41-51. http://dx.doi.org/10.1016/S0008-8846(97)00254-8.

12. Hernandez-Zaragoza, J.B.; Caballero-Badillo, C.E.; RosasJuarez, A.; Lopez-Lara, T.; Hinojosa-Torres, J.; Castano, V.M. (2007) Modification of Portland cement mortars with cactus gum. Chemistry and Chemical Technology. 1 [3], 175-177.

13. Ramírez-Arellanes, S.; Cano-Barrita, P.F. de J.; JuliánCaballero, F.; and Gómez-Yañez, C. (2012) Concrete durability properties and microstructural analysis of cement paste with nopal cactus mucilage as a natural additive. Mater. Construcc. 62 [302], 327-341. http://dx.doi.org/10.3989/mc. 2012.00211.

14. Leon-Martinez F.; Cano-Barrita P.F.J.; Lagunez-Rivera L.; Medina-Torres L. (2014) Study of nopal mucilage and marine brown algae extract as viscosity enhancing admixtures for cement based materials. Construct. Build. Mat. 53 [2], 190-202. http://dx.doi.org/10.1016/j.conbuildmat.2013.11.068.

15. Torres-Acosta A.A.; Martínez-Molina W.; Alonso-Guzmán E.M. (2012) State of the Art on Cactus Additions in Alkaline Media as Corrosion Inhibitors. International Journal of Corrosion. Article ID 646142, 9 pages, http://dx.doi.org/ 10.1155/2012/646142.

16. Fischer, F.G.; Dorfel, H. (1955) Polyuronic acids in brown algae. Hoppe-Seyler's Zeitschrift fur physiologische Chemie. 302 [4-6], 186-203. http://dx.doi.org/10.1515/bchm2.1955. 302.1-2.186

17. Haug, A.; Smidsrød, O. (1965) Fractionation of alginates by precipitation with calcium and magnesium ions. Acta Chem. Scand. 19, 1221-1226. http://dx.doi.org/10.3891/acta.chem. scand.19-1221.

18. Reyes-Tisnado, R.; Hernández-Carmona, G.; LópezGutiérrez, F.; Vernon-Carter, E.J.; Castro-Moyoroqui, P. (2004) Sodium and Potassium alginates extracted from Macrocystis Pyrifera algae for use in dental impression materials. Cienc. Mar. 30 [01B], 189-199. Online at http:// www.redalyc.org/articulo.oa?id=48003004.

19. Pathak, T.S.; Yun, J-H.; Lee, J.; Paeng, K-J. (2010) Effect of calcium ion (cross-linker) concentration on porosity, surface morphology and thermal behavior of calcium alginates prepared from algae (Undaria pinnatífida). Carbohyd. Polym. 81 [3], 633-639. http://dx.doi.org/10.1016/j.carbpol. 2010.03 .025 .

20. Galán-Marín, C.; Rivera-Gómez, C.; Petric, J. (2010) Claybased composite stabilized with natural polymer and fibre. Construct. Build. Mat. 24 [8], 1462-1468. http://dx.doi.org/ 10.1016/j.conbuildmat.2010.01.008.

21. Friedemann, K.; Stallmach, F; Karger, J. (2006) NMR diffusion and relaxation studies during cement hydration-A non-destructive approach for clarification of mechanism of internal post curing of cementitious materials. Cem. Concr. Res. 36 [5], 817-826. http://dx.doi.org/10.1016/j. cemconres.2005.12.007.

22. American Society for Testing Materials (ASTM) (2003) ASTM Standard C33-03: Standard Specification for Concrete Aggregates, West Conshohocken, PA, 11

23. American Society for Testing Materials (ASTM) (2001) ASTM Standard C70-01: Standard Test Method for Surface Moisture in Fine Aggregate, West Conshohocken, PA, 3.

24. American Society for Testing Materials (ASTM) (2001) ASTM Standard C127-01: Standard Test Method for Density, Relative Density (Specific Gravity), and Absorption of Coarse Aggregate, West Conshohocken, PA, 6.

25. American Society for Testing Materials (ASTM) (2001) ASTM Standard C128-01: Standard Test Method for Density, Relative Density (Specific Gravity), and Absorption of Fine Aggregate, West Conshohocken, PA, 6.

26. American Society for Testing Materials (ASTM) (2004) ASTM Standard C566-04: Standard Test Method for Total Evaporable Moisture content of Aggregate by Drying, West Conshohocken, PA, 3

27. American Society for Testing Materials (ASTM) (2003) ASTM Standard C29-03: Standard Test Method for Bulk Density ("Unit Weight") and Voids in Aggregate, West Conshohocken, PA, 4.

28. Medina-Torres, L.; Brito-De La Fuente, E.; TorrestianaSanchez, B.; and Katthain, R. (2000) Rheological properties of the mucilage gum (Opuntia ficus indica). Food Hydrocolloids. 14 [5], 417-424. http://dx.doi.org/10.1016/ S0268-005X(00)00015-1. 
29. Sáenz, C.; Sepúlveda, E. (1993) Alternativas de industrialización de la tuna (Opuntia ficus-indica). Alimentos. 18 [3], 29-32.

30. Sáenz, C.; Sepúlveda, E.; Matsuhiro, B. (2004) Opuntia spp mucilage's: a functional component with industrial perspectives. J. Arid. Environ. 57 [3], 275-290. http://dx.doi. org/10.1016/S0140-1963(03)00106-X.

31. Abrajan, M.A. (2008) Efecto del método de extracción en las características químicas y físicas del mucílago de nopal (Opuntia ficus-indica) y estudio de su aplicación como recubrimiento comestible. $\mathrm{PhD}$ Thesis, Spain: Universidad Politécnica de Valencia, 1-244.

32. McGarvie, D.; Parolis, H. (1979) The mucilage of Opuntia ficus indica. Carbohyd. Res. 69 [1], 171-179. http://dx.doi. org/10.1016/S0008-6215(00)85762-6.

33. Trachtenberg, S.H.; Mayer, A. (1981) Calcium oxalate crystals in Opuntia ficus indica (L.) Mill: development and relation to mucilage cells - a stereological analysis. Protoplasma 109 [3-4], 271-283. http://dx.doi.org/10.1007/ BF01287447.

34. Chhabra, R.P.; Richardson, J.F. (2008) Non-Newtonian flow and applied rheology. Second edition, Butterworth Heinemann, 536.

35. American Society for Testing Materials (ASTM) (1999) ASTM Standard C305-99: Standard Practice for Mechanical Mixing of Hydraulic Cement Pastes and Mortars of Plastic Consistency, West Conshohocken, PA, 3.

36. Fagerlund, G. (2009) Chemically bound water as measure of degree of hydration- Methods and potential errors. Report TVBM-3150, 31 .

37. Meiboom, S.; Gill, D. (1958) Modified spin-echo method for measuring nuclear relaxation times. Rev. Sci. Instrum. 29, 688-691. http://dx.doi.org/10.1063/1.1716296.

38. Aïtcin, P.C.; Mehta, K. (1990) Principles underlying production of high-performance concrete. The American Society for testing and materials, cement, concrete and aggregates. 12 [2], 70-78.

39. ACI Committee 211. (1991) Standard Practice for Selecting Proportions for Normal, Heavyweight, and Mass Concrete (ACI 211-1-91). American Concrete Institute, Farmington Hills, MI, 38 .

40. American Society for Testing Materials (ASTM) (2003) ASTM Standard C39-0: Standard Test Method for Compressive Strength of Cylindrical Concrete Specimens, West Conshohocken, PA, 5.

41. Hall, C. (1989) Water Sorptivity of Mortars and Concretes: A Review. Mag. Concrete Res. 41 [147], 51-61. http:// dx.doi.org/10.1680/macr.1989.41.147.51.

42. American Society for Testing Materials (ASTM) (1997) ASTM Standard C642-97: Standard Test Method for Density, Absorption, and Voids in Hardened concrete, West Conshohocken, PA, 3.

43. American Society for Testing Materials (ASTM) (1997) ASTM Standard C1202-97: Standard Test Method for Electrical Indication of Concrete's Ability to Resist Chloride Ion Penetration, West Conshohocken, PA, 6.
44. NT BUILD 443, NORDTEST METHOD. (1995) Concrete, hardened: accelerated chloride penetration. NORDTEST, Tekniikantie 12, FIN-02150 ESPOO, FINLAND, Approved 1995-11, 5.

45. Crank, J. (1975) The mathematics of diffusion, second edition, Oxford University Press, Oxford.

46. Bentz, D.P.; Snyder, K.A.; Cass, L.C.; Peltz, M.A. (2008) Doubling the Service Life of Concrete. I: Reducing Ion Mobility Using Nanoscale Viscosity Modifiers. Cement and Concrete Composites. 30, 674-678. http://dx.doi.org/ 10.1016/j.cemconcomp.2008.05.001.

47. Bentz, D.P.; Peltz, M.A.; Snyder, K.A.; Davis, J.M. (2009) VERDiCT: Viscosity Enhancers Reducing Diffusion in Concrete Technology. Concrete International. 31 [1], 31-36. Online at: http://concrete.nist.gov/ bentz/CI3101 Bentzreadonly.pdf.

48. Leemann, A.; Lothenbach, B.; Thalmann, C. (2011) Influence of superplasticizers on pore solution composition and on expansion of concrete due to alkali-silica reaction. Construct. Buid. Mat. 25, 344-350. http://dx.doi. org/10.1016/j.conbuildmat.2010.06.019.

49. Peschard, A.; Govin, A.; Grosseau, P.; Guilhot, B.; Guyonnet, R. (2004) Effect of polysaccharides on the hydration of cement paste at early ages. Cem. Concr. Res. 34, 2153-2158. http://dx.doi.org/10.1016/j.cemconres.2004.04.001.

50. Mehta, P.K.; and Monteiro, P.J.M. (2006) Concrete Microstructure, Properties, Materials. Third Edition, McGraw-Hill Companies, Inc. 684.

51. Coates, G.R.; Xiao, L.; Prammer, M.G. (1999) NMR Logging Principles Applications. Halliburton Energy Service, 234.

52. Trachtenberg S.; Mayer M. (1982) Biophysical properties of Opuntia ficus-indica mucilage. Phytochemistry. 21 [12], 2835-2843. http://dx.doi.org/10.1016/0031-9422(80)85052-7.

53. De Larrard F.; Aitcin P.C. (1993) Apparent strength retrogression of silica-fume concrete. ACI Materials Journal. 90 [6], 581-585. http://dx.doi.org/10.14359/4434.

54. Hughes, D.C. (1985) Pore Structure and Permeability of Hardened Cement Paste. Magazine of Concrete Research. 37 [133], 227-233. http://dx.doi.org/10.1680/macr.1985. 37.133 .227 .

55. Caballero, J.F. (2008) Secado, absorción de agua y difusión de cloruros en concreto conteniendo extracto de nopal. MSc. Thesis, Oaxaca, México: CIIDIR IPN, 1-116.

56. Poinot, T.; Govin, A.; Grosseau, P. (2014) Influence of hydroxypropylguars on rheological behavior of cement-based mortars. Cem. Concr. Res. 58, 161-168. http://dx.doi.org/ 10.1016/j.cemconres.2014.01.020.

57. Ventolà, L.; Vendrell, M.; Giraldez, P.; Merino, L. (2011) Traditional organic admixtures improve lime mortars: New old materials for restoration and building natural stone fabrics. Construct. Build. Mat. 25 [8], 3313-3318. http://dx.doi.org/10.1016/j.conbuildmat.2011.03.020.

58. Sisomphon, K.; Franke, L. (2007) Carbonation rates of concretes containing high volume of pozzolanic materials. Cem. Concr. Res. 37 [12], 1647-1653. http://dx.doi.org/ 10.1016/j.cemconres.2007.08.014 